\title{
電子装置設置環境の腐食性を評価するための腐食センサ*
}

\author{
南谷林太郎**, 天沼 武 宏***, 松井 清 ${ }^{\dagger}$ \\ $* *$ 株式会社日立製作所 機械研究所 \\ *** 株式会社日立製作所 情報制御システム事業部 \\ †株式会社日立製作所 エンタープライズサーバ事業部

\section{Corrosion Sensors to evaluate Corrosiveness of Installation Environment for Electronic Equipment*} \\ Rintaro Minamitani** ${ }^{*}$, Takehiro Amanuma*** and Kiyoshi Matsui ${ }^{\dagger}$ \\ ** Mechanical Engineering Research Laboratory, Hitachi, Ltd. \\ *** Information and Control Systems Division, Hitachi, Ltd. 栜 \\ ${ }^{\dagger}$ Enterprise Server Division, Hitachi, Ltd.
}

\begin{abstract}
We developed original corrosion sensors, an in-situ measurement type corrosion sensor and an electrical resistance type corrosion sensor, to evaluate the corrosiveness of installation environments for electronic equipment. The in-situ measurement type corrosion sensor measures the approximate corrosion thickness using the difference between a non-corroded metal color and a corrosion film color. The sensor does not require any professional instrumental analysis knowledge. The electrical resistance type corrosion sensor accurately measures the continuous corrosion thickness using electrical resistance change coupled with the metal electrode cross-section. In this paper, we constructed trial corrosion sensors made of silver film used extensively in electronic devices. First, we investigated the corrosion behavior in silver film of corrosion sensors and in the conventional silver coupon. As the silver film was corroded by the same mechanism as the silver coupon was corroded when exposed to a mixed corrosive gas, we can measure corrosion thickness of silver film exposed to a corrosive environment with the corrosion sensors instead of the silver coupon. Next, we used the corrosion sensors to investigate the corrosiveness of the environment in a heavy industrial plant and an office with a computer installed. The in-situ measurement type corrosion sensor is suitable for investigating the corrosiveness of severe corrosive environment, while the electrical resistance type corrosion sensor is suitable for investigating the corrosiveness of weak corrosive environment. We proved that these corrosion sensors are effective for evaluating the corrosiveness of installation environments for electronic equipment.
\end{abstract}

Key words : corrosion sensor, in-situ measurement, electrical resistance measurement, atmospheric corrosion, corrosive gas, electronic equipment

\section{1. 緒言}

電子装置では，搭載される電子部品のわずかな腐食が 電気特性, 磁気特性に変化を与えて故障や誤動作の原因 となる. 電子部品の腐食を抑制するためには, 電子材料 へのアプローチよりも，腐食環境の形成を阻止する環境 制御や構造制御のアプローチが有効であると指摘された1). ただし, 電子装置は購入品を含めて多数の電子部品で構 成されているため, すべての電子部品に対して構造制御 のアプローチとして耐食構造設計を行うことは困難であ る。そこで, 温湿度, 腐食性ガス, 塵埃などの腐食要因 を除去する環境制御のアプローチが有効となる.すなわ ち, 電子装置の設置環境の腐食性を評価して, その評価 結果に基づき空調やフィルタリングにより環境を改善す るアプローチである。

* 第 47 回材料と環境討論会 (山口, 2000 年), 材料と環境 2001 (つ くば，2001年)，第48年材料と環境討論会（札幌，2001年)，材料と 環境2002(川崎, 2002年)

** テ312-0034ひたちなか市堀口 832-2 (832-2, Horiguchi, Hitachinaka, 312-0034 Japan)

*** 厂 319-1293，日立市大みか町 5-2-1 (2-1, Omika 5, Hitachi, 3191293 Japan)

† ₹259-1392 秦野市堀山下 1 (1 Horiyamashita, Hadano, 259-1392 Japan)
これまで電子装置の設置環境の腐食性を評価するため に, 温湿度, 腐食性ガス, 塵埃などの腐食要因を定量化 して総合的に評価する方法 ${ }^{2}$, 各腐食要因の複合化され た結果として金属の腐食量から評価する方法3),4) が提案 されている。このうち金属の腐食量を測定する方法とし ては，積算測定法または連続測定法がある。積算測定法 ではカソード還元法3),4)，化学分析法5),6)により金属試験 片の平均腐食量を, 連続測定法では例えば水晶振動子微 量天秤法 (Quartz Crystal Microbalance) ${ }^{7), 8)}$ により金属薄 膜電極の瞬間腐食量を測定する。ここで，積算測定法で は腐食量のその場測定が難しいこと, 連続測定法では高 価で特殊な測定系を必要とすることが課題となる.

本研究では, 電子装置の設置環境の腐食性を金属の腐 食量により評価する方法に注目して, 機器分析を必要と しないその場測定型腐食センサ，低コストで簡単な測定 系からなる連続測定が可能な電気抵抗型腐食センサを試 作した.さらに，試作した腐食センサを電子装置の設置 環境に曝露して，その有効性を検討した。

\section{2. 腐食センサの原理}

\section{1 その場測定型腐食センサ}

その場測定型腐食センサは，透明基板とその基板上に 段階的に膜厚が異なるように形成された金属薄膜とで構 


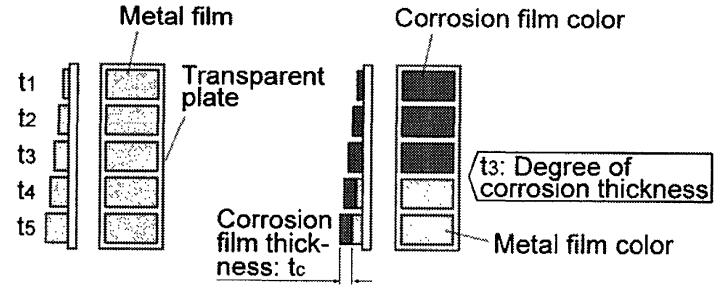

(a) Initial

(b) After exposure

Fig. 1. Principle of in-situ measurement type corrosion sensor.

成されている（Fig. 1(a) では，例として膜厚 $t_{1} \sim t_{5}$ の 5 種類の金属薄膜で構成)。腐食センサを環境に曝露する と，金属薄膜は曝露面側（側面図で左側）から腐食する. ここでは，厚さ $t_{\mathrm{c}}$ の腐食皮膜を形成した場合を考える (Fig. 1(b)). 膜厚 $t_{1}, t_{2}, t_{3}$ の金属薄膜では透明基板の界面 まですべて腐食しているのに対し, 膜厚 $t_{4}, t_{5}$ の金属薄膜 では透明基板の界面まで腐食皮膜が到達していない，透 明基板を通して（側面図で右側から）腐食センサを観察 すると, 膜厚 $t_{1}, t_{2}, t_{3}$ の金属薄膜は腐食皮膜の色調に変化 しているが, 膜厚 $t_{4}, t_{5}$ の金属薄膜は金属の色調のままで ある.このように金属薄膜と腐食皮膜の色調の違いを目 視で判断することにより, 金属薄膜の腐食厚さレベルを 測定できる，なお，腐食センサの測定範囲および測定感 度は，金属薄膜の膜厚により調整できる。

さらに, 蛍光 X 線分析装置 (OXFORD 製 WDX400, 以 下 XRFS と記す, 分析条件: 加速電圧 $20 \mathrm{kV}$, 試料電流 $10 \mathrm{nA}$ ，分析エリア $\square 200 \mu \mathrm{m} ）$ を用いて腐食皮膜を含む金 属薄膜における検出元素の原子数濃度を測定することに より，金属薄膜の腐食厚さを精度良く算出できる。例と して, $\mathrm{Ag}$ 薄膜が硫化して $\mathrm{Ag}_{2} \mathrm{~S}$ からなる腐食皮膜を形成 した場合を考える. $\mathrm{Ag}$ 薄膜の腐食厚さ $t_{\mathrm{c}}$ は式(1) で表さ れる。

$$
t_{\mathrm{c}}=t_{0} \cdot 2 C_{\mathrm{S}} / C_{\mathrm{Ag}}
$$

ここで, $t_{0}$ は $\mathrm{Ag}$ 薄膜の初期厚さ, $C_{\mathrm{Ag}}, C_{\mathrm{S}}$ は $\mathrm{Ag}_{2} \mathrm{~S}$ の腐食 皮膜を含む $\mathrm{Ag}$ 薄膜に扮ける $\mathrm{Ag}, \mathrm{S}$ の原子数濃度を表す. この方法では, $\mathrm{Ag}$ 薄膜が十分に薄く $\mathrm{X}$ 線が下地基板 (こ こでは透明基板）まで侵入することを前提として， $\mathrm{Ag}$ と $\mathrm{S}$ の原子数濃度を測定する.このため, XRFS の X 線強 度が変動しても, 原子数濃度比 $2 C_{\mathrm{S}} / C_{\mathrm{Ag}}$ は常に一定に保

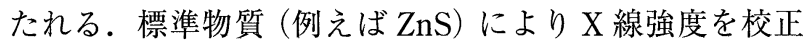
する必要はない。なお，下地基板に含まれる $\mathrm{S}$ 成分は検 出限界以下であったため, これによる補正は行わなかっ た。

\section{2 電気抵抗型腐食センサ}

電気抵抗型腐食センサは, 絶縁基板とその基板上に形 成された金属薄膜電極とで構成されている (Fig. 2). 電 極に金属薄膜を採用することにより，寸法精度が高いた め再現性の良い，断面積が小さいため感度の高いセンサ を構築できる，腐食センサを環境に曝露すると，金属薄 膜電極が曝露面側 (図で上側) から腐食する。ここでは, 厚さ $t_{\mathrm{c}}$ の腐食皮膜を形成した場合を考える．金属薄膜が 均一な腐食皮膜を形成すること，その腐食皮膜が絶縁体 であること（もしくは腐食皮膜の電気抵抗值が金属薄膜 のそれに比べて十分に大きいこと）を仮定すると，以下 のように金属薄膜電極の腐食厚さを電気抵抗値として測

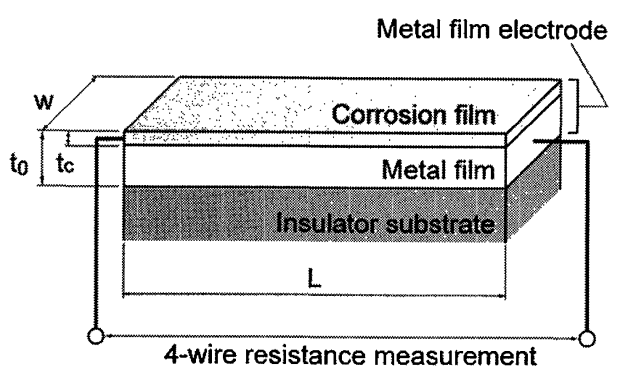

Fig. 2. Principle of electrical resistance type corrosion sensor.

定できる.

初期における金属薄膜電極の電気抵抗值 $R_{0}$ は式 (2) で 表される.

$$
R_{0}=\rho \cdot L /\left[w \cdot t_{0}\right]
$$

ここで, $t_{0}, w, L$ は金属薄膜電極の初期厚さ, 幅, 長さ, $\rho$ は金属薄膜の体積抵抗率である. また，厚さ $t_{\mathrm{c}}$ の腐食 皮膜を形成した金属薄膜電極の電気抵抗值 $R_{1}$ は式 (3) で表される。

$$
R_{1}=\rho \cdot L /\left[w \cdot\left(t_{0}-t_{\mathrm{c}}\right)\right]
$$

式 (2) と式 (3) から，金属薄膜電極の腐食厚さ $\mathrm{t}_{\mathrm{c}}$ は式 (4) で表される.

$$
t_{\mathrm{c}}=t_{0} \cdot\left[1-\left(R_{0} / R_{1}\right)\right]
$$

なお，腐食厚さ $t_{\mathrm{c}}$ は，金属薄膜電極の幅 $w$, 長さ $L$ に依 存しない。 また, 腐食センサの測定範囲および測定感度 は，金属薄膜の膜厚により調整できる。

\section{3. 実 験 方 法}

\section{1 その場測定型腐食センサ}

\subsection{1 試作方 法}

金属薄膜材料には，電子材料として実績があり，また 腐食性ガス (特に還元性硫黄)に対して感受性が高い $\mathrm{Ag}$ を採用した。基板には透明ソーダライムガラス（100× $100 \times 1 \mathrm{~mm}$ ) を用い, それを洗浄（セリウム手研磨, 水 洗, アルカリ超音波洗浄, 市水超音波洗浄, 温純水乾 燥）後に, 所定の寸法にハーフダイシングした。この基 板上に $\mathrm{Ag}$ 薄膜を DC マグネトロンスパッタ装置 (ターゲ ット：Ag $(99.99 \%)$, 背圧 : $<4.0 \times 10^{-4} \mathrm{~Pa}$, スパッタガ ス：Ar，スパッ夕压: $4.0 \times 10^{-1} \mathrm{~Pa}$, 投入電力 : $0.8 \mathrm{~A} \times$ $358 \mathrm{~V})$ により形成した。

$\mathrm{Ag}$ 薄膜の表面形状を走査型電子顕微鏡（以下 SEM と 記す）により観察し, その膜厚を接触式段差計により測 定した.さらに，その密度を物理法により算出した。こ こで，透明ソーダライムガラス基板 $(100 \times 100 \times 1 \mathrm{~mm})$ に形成した $\mathrm{Ag}$ 薄膜の重量を酸分解高周波誘導結合プラ ズマ発光分光法 (以下 ICP と記す) により測定し, また その体積を薄膜の膜厚とスパッ夕面積（基板寸法）から 算出した.

試作したその場測定型腐食センサを Fig. 3 に示す. 膜 厚 $24,36,69,100,159 \mathrm{~nm}$ (成膜後に膜厚を測定)の $\mathrm{Ag}$ 薄 膜を形成したガラス基板をそれぞれ $12 \times 6 \mathrm{~mm}$ に切断し た後, 膜厚順に並べて非成膜面側から観察できるように 透明ケースに取り付けた。 また, $\mathrm{Ag}$ 薄膜の下半分を成 膜面側から透明テープでコーティングして金属薄膜の色 調を保持することにより，曝露後に金属薄膜と腐食皮膜 


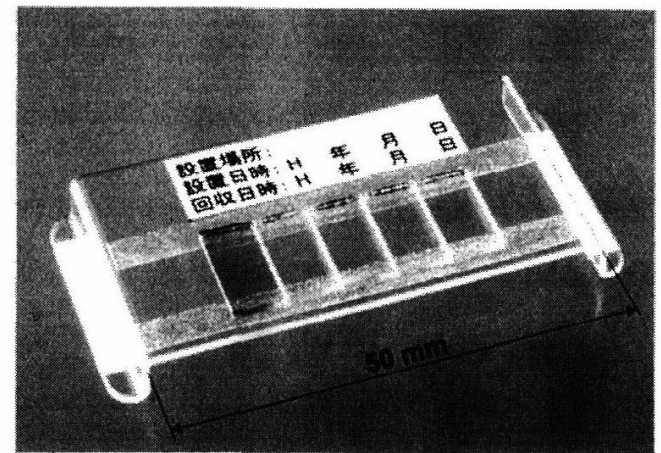

Fig. 3. A photograph of in-situ measurement type corrosion sensor.

の色調の違いを判別しやすくした.

\section{1 .2 基 礎 試 験}

試作腐食センサを，電子部品の大気腐食に対する促進 試験環境 $\left(\mathrm{NO}_{2}: 1.0 \mathrm{ppm}, \mathrm{SO}_{2}: 1.0 \mathrm{ppm}, \mathrm{H}_{2} \mathrm{~S}: 0.5 \mathrm{ppm}\right.$, $35^{\circ} \mathrm{C}, 75 \% \mathrm{RH}$, 以下混合ガス環境と記す) ${ }^{9)}$ に曝露した。 所定期間ごとに腐食センサを取り出して, Ag 薄膜の腐 食厚さを目視測定した。比較対象として， $\mathrm{Ag}$ 板試験片 （純度 99.9\%）を同一の混合ガス環境に曝露して，カソー ド還元法（窒素脱気 $0.1 \mathrm{~N}-\mathrm{KCl}$ 水溶液，カソード電流密 度-0.02 mA/ $\mathrm{cm}^{2}$, 窒温 ${ }^{10)}$ によりその腐食皮膜の同定と 腐食厚さを測定した。

また, 電子装置の設置環境（後述する重工業プラント の電気室）に曝露した腐食センサを用いて，膜厚の異な る $\mathrm{Ag}$ 薄膜の腐食厚さをXRFSに基づく方法で測定した。 すなわち, 腐食皮膜を含む $\mathrm{Ag}$ 薄膜の $\mathrm{Ag}$ と Sの原子数 濃度をXRFS 分析により測定し, その原子濃度比 $2 C_{\mathrm{S}} / C_{\mathrm{Ag}}$ から $\mathrm{Ag}$ 薄膜の腐食厚さを式 (1) により算出し た.

\subsection{3 設置環境の測定}

重工業プラント(茨城県) の工程ごとに配置されてい る 5 箇所 (工程 $\mathrm{A} \sim \mathrm{E}$ ) の電気室（制御装置を設置した部 屋）に，試作したその場測定型腐食センサを 2 力月間曝 露し， $\mathrm{Ag}$ 薄膜の腐食厚さを月視測定した．さらに上記 腐食センサの膜厚 $159 \mathrm{~nm}$ の $\mathrm{Ag}$ 薄膜を用いて，その腐食 厚さをXRFS 分析に基づく方法で測定した.

\section{2 電気抵抗型腐食センサ}

\subsection{1 試作方法}

$\mathrm{Ag}$ 薄膜電極はその場測定型腐食センサで用いた $\mathrm{Ag}$ 薄 膜と同一プロセスで形成して抢り，ここではその説明を 省略する.

試作した電気抵抗型腐食センサの $\mathrm{Ag}$ 薄膜電極の形状 を Fig. 4 に示す. 膜厚 $t=267 \mathrm{~nm}$, 長さ $L=6,11,21$ $\mathrm{mm}$, 幅 $w=0.25,0.5,1.0 \mathrm{~mm}$ の組合せで合計 9 種類の $\mathrm{Ag}$ 薄膜電極を作成した．電極の両側に設けたパッド部 に抵抗測定用リード線（各パッド 2 本）を導電性接着剤 で接合し，さらに接合部を腐食防止のためにエポキシ接 着剂で封止した。

$\mathrm{Ag}$ 薄膜電極の電気抵抗の測定は, 配線抵抗や接触抵 抗を除くため，4端子抵抗法を採用した。まず， $\mathrm{Ag}$ 薄膜 電極の初期特性として，試作した全種類の $\mathrm{Ag}$ 薄膜電極

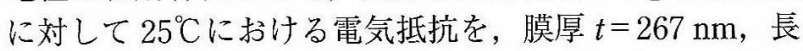

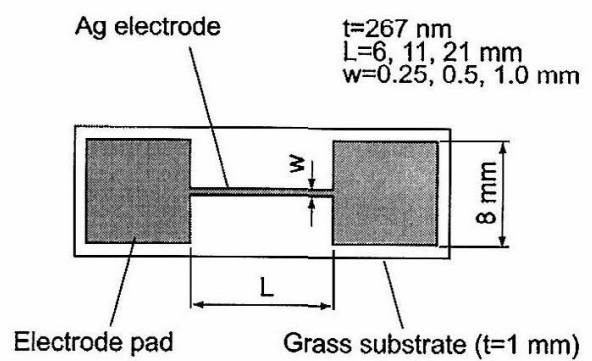

Fig. 4. Schematic diagram of Ag electrode in electrical resistance type corrosion sensor.

さ $L=11 \mathrm{~mm}$, 幅 $w=0.5 \mathrm{~mm}$ の $\mathrm{Ag}$ 薄膜電極に対して恒

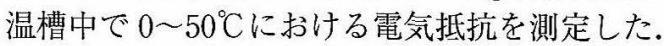

\section{2 .2 基礎試験}

電気抵抗型腐食センサを，その場測定型腐食センサと 同じく混合ガス環境に曝露し， $\mathrm{Ag}$ 薄膜電極の電気抵抗 を 3 分間隔で测定した。测定した電気抵抗值から Ag 薄 膜の腐食厚さを式(4)により算出した.

\subsection{3 設置環境の測定}

電子計算機を設置した一般のオフィス（茨城県）に， 試作した電気抵抗型腐食センサを 1 力月間嚗露した。曝 露期間にわたり $\mathrm{Ag}$ 薄膜の電気抵抗，および温湿度を 3 分間隔に測定した，測定した電気抵抗值から $\mathrm{Ag}$ 薄膜の 腐食厚さを式(4)により算出した。また，比較対象とし て, 専用の電子計算機室に Ag 板試験片を嚗露し, カソ ード還元法によりその腐食厚さを測定した。

\section{4. 実 験 結 果}

\section{1 その場測定型腐食センサ}

\subsection{1 試作結果}

DC マグネトロンスパッタ装置を用いて形成した膜厚 $24 \mathrm{~nm}, 159 \mathrm{~nm}$ (成膜後に膜厚を测定)の $\mathrm{Ag}$ 薄膜表面の SEM 観察結果怘 Fig. 5 に示す. Ag 薄膜はガラス基板に 全面均一に塊状で形成され，膜厚が厚くなると粒の粗大 化が認められた. 膜厚 $159 \mathrm{~nm} の \mathrm{Ag}$ 薄膜に対して, 物理 法により求めた密度は， $8.8 \mathrm{~g} / \mathrm{cm}^{3}$ となった。この值は, バルク $\mathrm{Ag}$ の值 $10.5 \mathrm{~g} / \mathrm{cm}^{3}$ 11) に比べて約 $16 \%$ 小さい. なお，膜厚 $24 \mathrm{~nm}$ の $\mathrm{Ag}$ に対しては，ICPによる $\mathrm{Ag}$ 薄 膜の重量測定が困難であったため，密度を測定しなかっ た. $\mathrm{Ag}$ 薄膜は, 塊状の表面形状であることから表面積 が大きい上に密度が低いため，Ag 板に対して腐食され やすい.

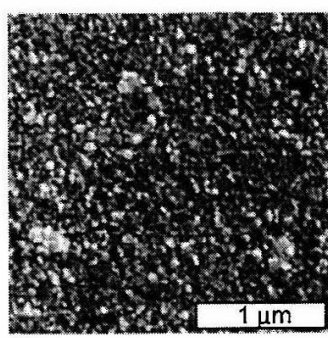

(a) $24 \mathrm{~nm}$

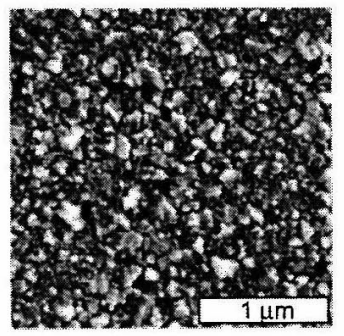

(b) $159 \mathrm{~nm}$

Fig. 5. Scanning electron micrographs of initial Ag sputtered films (a) $24 \mathrm{~nm}$, (b) $159 \mathrm{~nm}$. 

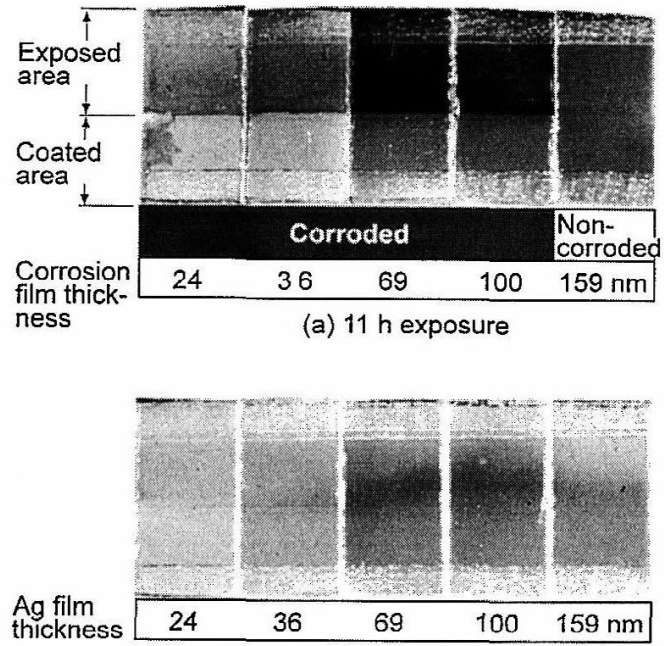

(b) Before exposure (initial)

Fig. 6. Appearance of $\mathrm{Ag}$ films of in-situ measurement type corrosion sensors exposed to a mixed gas (a) and before exposure (b).

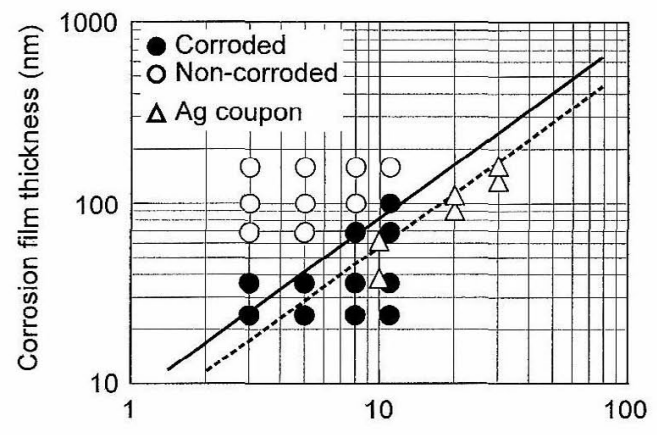

Exposure time (h)

Fig. 7. Relationship between exposure time and corrosion film thickness of Ag film in in-situ measurement type corrosion sensors exposed to a mixed gas.

\subsection{2 基礎試験結果}

混合ガス環境に $11 \mathrm{~h}$ 曝露したその場測定型腐食センサ の外観写真を Fig. 6(a) に示す.コーティングを施した下 半分の $\mathrm{Ag}$ 薄膜は, $11 \mathrm{~h}$ 曝露後でも初期 (Fig. 6(b)) と同 じ金属溥膜の色調を保持していることを確認した.コー ティングを施した金属薄膜の色調を基準にして観察する と, 膜厚 $24 \sim 100 \mathrm{~nm}$ の $\mathrm{Ag}$ 薄膜は腐食皮膜の色調 (茶色 または紫色), 一方 $159 \mathrm{~nm}$ の $\mathrm{Ag}$ 薄膜は金属の色調のま まであることがわかる。このように腐食センサの目視観 察から， $\mathrm{Ag}$ 薄膜の腐食厚さは $100 〜 159 \mathrm{~nm}$ の間にある と测定できる．所定期間ごとに取り出したその場測定型 腐食センサの目視測定結果をまとめて, 混合ガス環境に 曝露した $\mathrm{Ag}$ 薄膜の腐食厚さの経時変化を Fig. 7 に示す. 実線はその場測定型腐食センサによる腐食厚さ，点線は カソード還元法による $\mathrm{Ag}$ 板試験片の腐食厚さに対する 推定線を示す. $\mathrm{Ag}$ 薄膜および $\mathrm{Ag}$ 板試験片の腐食厚さは, 志賀らの報告12) と同様に直線則に従い增加した. ただし， $\mathrm{Ag}$ 皮膜の腐食厚さは, $\mathrm{Ag}$ 板試験片のそれに比べて約 $20 \%$ 大きな值を示した。また，3 $\mathrm{h}$ 曝露した腐食センサ の腐食厚さは, 直線則 (図中の実線) 加外れて, 過大 な値 $(36 \mathrm{~nm})$ を示した。

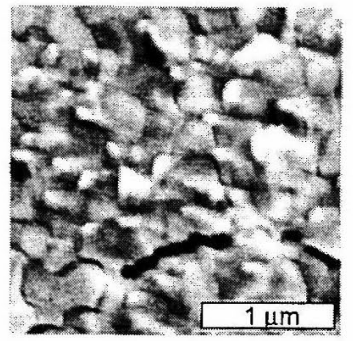

(a) Ag sputtered film (159nm)

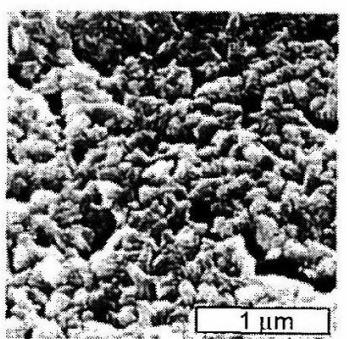

(b) Ag coupon
Fig. 8. Scanning electron micrographs of corrosion films on $\mathrm{Ag}$ sputtered film (a) and coupon (b) exposed to a mixed gas.

混合ガス環境に曝露したその場測定型腐食センサの $\mathrm{Ag}$ 薄膜 (厚さ $159 \mathrm{~nm}$ ) および $\mathrm{Ag}$ 板試験片の SEM 観察 結果を Fig. 8 にボす. $\mathrm{Ag}$ 薄膜では全面に凹凸のある粒状 の腐食皮膜が，さらにその腐食皮膜にき裂が観察された。 $159 \mathrm{~nm}$ 以外の $\mathrm{Ag}$ 薄膜でも，その腐食皮膜は同じ表面形 態を示した。 $\mathrm{Ag}$ 板試験片では，Ag 薄膜と同様に凹凸の ある粒状の腐食皮膜が，さらにその腐食皮膜にき裂が観 察された。また，初期に形成された研磨痕は曝露後に観 察されず，試験片表面に厚い腐食皮膜が形成されている ことがわかった．なお，この腐食皮膜は，XRFS 分析よ り下地基板のガラス成分 $\mathrm{Na}, \mathrm{Mg}, \mathrm{Al}, \mathrm{Si}, \mathrm{Ca}$ に加えて $\mathrm{Ag}$, $\mathrm{S}$ が検出されたこと, $\mathrm{Ag}$ 板試験片のカソード還元電位が $\mathrm{Ag}_{2} \mathrm{~S}$ の電位 $(-623 \mathrm{mV}$ vs. SHE) 10) を示したことから, $\mathrm{Ag}_{2} \mathrm{~S}$ の単層膜であると同定した。

重工業プラントの電気室に曝露した腐食センサを用い て, XRFS 分析に基づく方法で Ag 薄膜の腐食厚さを测定 した. 目視観察から $\mathrm{Ag}$ 薄膜の腐食量は $100 \mathrm{~nm}$ であった ため，本測定法は膜厚 $100 \mathrm{~nm}, 159 \mathrm{~nm}$ の $\mathrm{Ag}$ 薄膜にの み適用した. XRFS 分析による原子数濃度比は, 膜厚 100 $\mathrm{nm}, 159 \mathrm{~nm}$ の $\mathrm{Ag}$ 薄膜で，それぞれ $2 C_{\mathrm{S}} / C_{\mathrm{Ag}}=75.2 \%$ ， 47.0\%となった.これらの值を式（1）に代入して，膜厚 $100 \mathrm{~nm}, 159 \mathrm{~nm}$ の Ag 薄膜における腐食量は共に $75 \mathrm{~nm}$ となった．膜厚の異なる $\mathrm{Ag}$ 薄膜でも同一の腐食厚さを 示したことから XRFS 分析に基づく方法は標準物質なし に腐食厚さを精度よく測定できることを確認した。

\subsection{3 設置環境の測定結果}

重工業プラント (岑城県) の工程ごとに配置されてい る 5 筒所（工程 $\mathrm{A} \sim \mathrm{E}$ ) の電気室（制御装置を設置した部 屋）に掠いて，その場測定型腐食センサにより腐食厚さ を目視測定した結果を Fig. 9 に示す。ここで, 工程 A $\mathrm{D}$ の電気室の周囲環境では $0.31 \sim 0.5 \mathrm{ppm}$, 工程 $\mathrm{E} の$ 電 気室の周囲環境ではく0.1 ppm の $\mathrm{H}_{2} \mathrm{~S}$ ガスが検出された. 工程 $\mathrm{E}$ の電気室に比べて $\mathrm{H}_{2} \mathrm{~S}$ ガス濃度が高い工程 $\mathrm{A} \sim \mathrm{D}$ の電気室で腐食厚さは大きな值を示しており, $\mathrm{Ag}$ の腐 食は $\mathrm{H}_{2} \mathrm{~S}$ ガス濃度と共に促進すること12）を確認した。 ま た工程 D の電気室環境は，あらかじめ腐食による障害が 懸念されたため, 気密度の向上とガス吸着フィルタ設置 による環境改善が既に施されていた，腐食厚さの目視測 定結果は工程 $\mathrm{A} \sim \mathrm{C}$ の電気室環境に比べて小さい值を示 しており，環境改善の効果が現れていることを確認し た。

腐食皮膜の厚さをXRFS 分析に基づく方法で測定した 結果を Fig. 9 に併記した. その測定結果を基準にすると， 


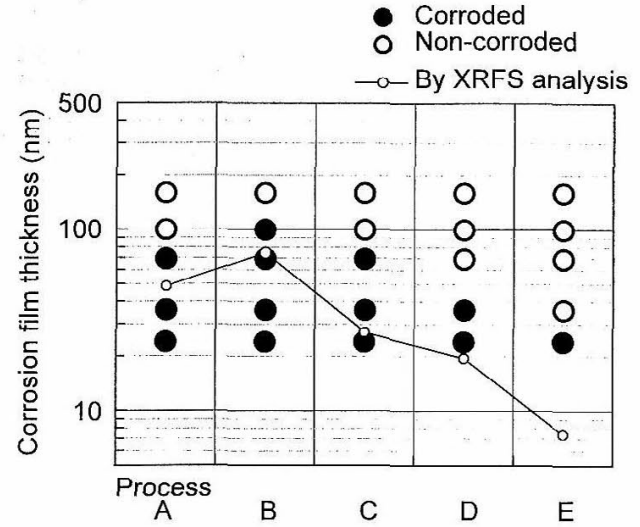

Fig. 9. Corrosion film thickness of Ag film in in-situ measurement type corrosion sensors exposed to five electric rooms in a heavy industrial plant (2-months exposure).

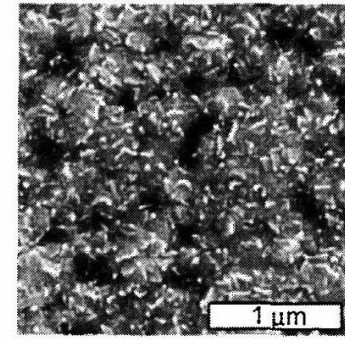

(a) Process B

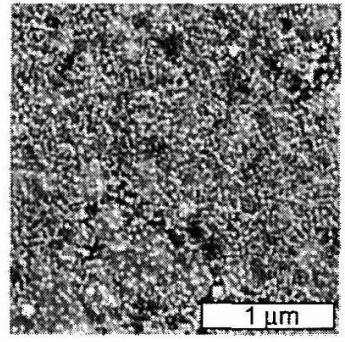

(b) Process E
Fig. 10. Scanning electron micrographs of corrosion films on $\mathrm{Ag}$ films in in-situ measurement type corrosion sensors exposed to different electric rooms in a heavy industrial plant (2-months exposure).

目視測定結果は同様の傾向を示した。ただし，腐食厚さ が $30 \mathrm{~nm}$ 以下であった工程 $\mathrm{C} \sim \mathrm{E}$ の電気室環境における 目視測定結果は，過大な値を示した。

工程 $\mathrm{B}, \mathrm{E}$ の電気室に曝露した腐食センサにおいて，膜 厚 $159 \mathrm{~nm}$ の $\mathrm{Ag}$ 薄膜の SEM 観察結果を Fig. 10 に示す. Fig. 9 に示した腐食厚さに対応して, 工程 $\mathrm{E} の$ 電気室環 境では微細な粒状の腐食皮膜が，工程 B の電気室環境で は数 $100 \mathrm{~nm}$ 径の凹凸のある厚い腐食皮膜が観察された。

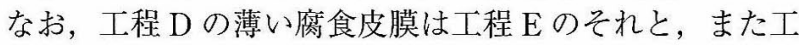
程 $\mathrm{A}, \mathrm{C}$ の厚い腐食皮膜は上程 $\mathrm{B}$ のそれと類似した表面 形態を示した. $\mathrm{H}_{2} \mathrm{~S}$ ガス濃度が高い環境では，微細な粒 状の腐食皮膜が成長して, Fig. 8 に示した混合ガス環境 に曝露した $\mathrm{Ag}$ 薄膜と同様に凹凸のある厚い腐食皮膜が 形成されたものと考兄られる. Ag 薄膜の XRFS 分析では, 共に下地基板のガラス成分 $\mathrm{Na}, \mathrm{Mg}, \mathrm{Al}, \mathrm{Si}, \mathrm{Ca}$ に加えて $\mathrm{Ag}, \mathrm{S}$ が検出された。腐食皮膜は $\mathrm{Ag}_{2} \mathrm{~S}$ の単層膜であると 同定した。

\section{2 電気抵抗型腐食センサ \\ 4.2.1 試作結 果}

試作した電気抵抗型腐食センサの $\mathrm{Ag}$ 薄膜電極に打い て, 電気抵抗と電極長さ/(幅 $\times$ 膜厚) との関係を Fig. 11 に示す.式(2)に示したように，その電気抵抗は電極長 さ/(幅×膜厚)に比例して増加した. 図中の直線の傾き で表される $\mathrm{Ag}$ 薄膜電極の体積抵抗率は $3.2 \times 10^{-6} \Omega \mathrm{m}$ で あり，バルク $\mathrm{Ag}$ の值 $1.6 \times 10^{-6} \Omega \mathrm{mm}^{11)}$ に比べて約 2 倍

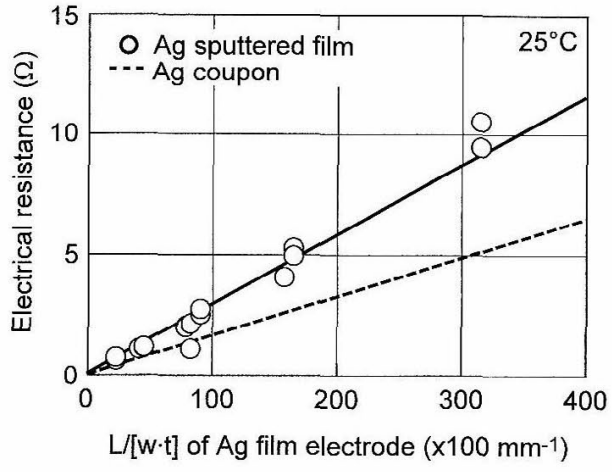

Fig. 11. Electrical resistance change of Ag electrodes in electrical resistance type corrosion sensors.

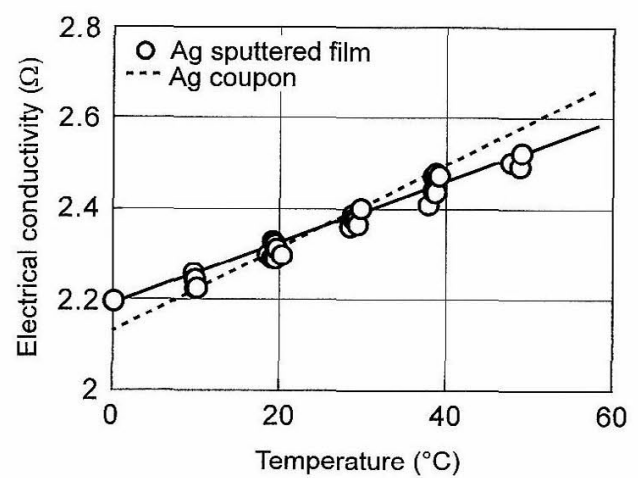

Fig. 12. Temperature dependence of electrical resistance of $\mathrm{Ag}$ electrode in electrical resistance type corrosion sensor.

大きい。これは, $\mathrm{Ag}$ 薄募電極の密度が低いことに起因 していると考えられる. また, $\mathrm{Ag}$ 薄膜電極（膜厚 $t=267$ $\mathrm{nm}$, 長さ $L=11 \mathrm{~mm}$, 幅 $w=0.5 \mathrm{~mm}$ ）の電気抵抗の温度 依存性を Fig. 12 に示吉。年の電気抵抗は, 温度に比例し て增加した. 図中の直線の傾きで表される $\mathrm{Ag}$ 薄膜の温 度係数は $0.28 \% /{ }^{\circ} \mathrm{C}\left(25^{\circ} \mathrm{C}\right.$ 基準)であり,バルタ $\mathrm{Ag}$ の值 $0.38 \% /{ }^{\circ} \mathrm{C} 11$ に比べて約 $25 \%$ 小さい.

\subsection{2 基礎試験結果}

混合ガス環境に曝露した 3 種類の電気抵抗型腐食セン サ（膜厚 $t=267 \mathrm{~nm}$, 長さ $L=11 \mathrm{~mm}$, 幅 $w=0.25,0.5,1.0$ $\mathrm{mm}$, 各 2 個）による $\mathrm{Ag}$ 薄膜の腐食厚さの経時変化を Fig. 13 に示す．その腐食厚さは，電極の幅寸法に依存せ ず直線則に従い增加した。ただ，腐食厚さは， $30 \mathrm{~nm}$ を超えた付近から，直線則から外れて過大な值を示した． また，同じ幅の $\mathrm{Ag}$ 薄膜電極では約 30\%，異なる幅の $\mathrm{Ag}$ 薄膛電極では約 $60 \%$ の腐食厚さのばらつきを生じた.

\subsection{3 設置環境の測定結果}

電子計算機を設置した一般のオフィスにおいて，電気 抵抗型腐食センサにより腐食厚さを連綂測定した結果を Fig. 14 に，その哑境の温湿度を連続测定した結果を Fig. 15 に示す. $\mathrm{Ag}$ 薄膜の腐食厚さは, 直線則に従い增加し, 屋内環境の測定結果とほぼ一致した ${ }^{13)}$. 比較として, 専 用の計算機室に曝露した $\mathrm{Ag}$ 板試験片の腐食厚さを Fig. 14 に併記した。一般のオフィス環境は, 専用の計算機室 環境に比べて腐食性が高いことを確認した。

今回測定した事務所では, 空調機の運転と停止により 温湿度が変動しており, 温度は $20 \sim 35^{\circ} \mathrm{C}$, 相対湿度は 20〜60\%RH であった. Fig. 14 で示した Ag 薄膜の腐食 


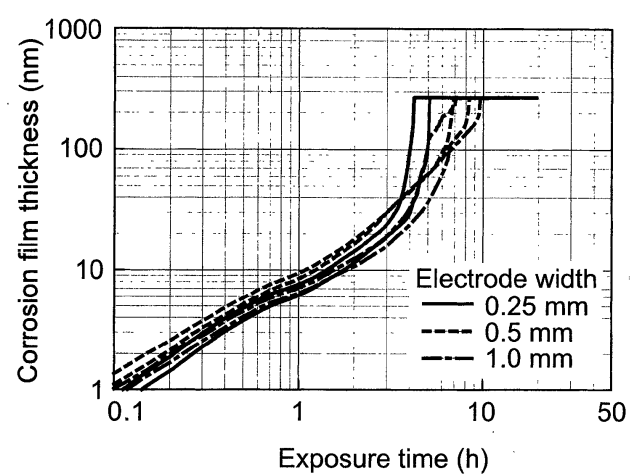

Fig. 13. Corrosion film thickness change of Ag film in electrical resistance type corrosion sensors exposed to a mixed gas.

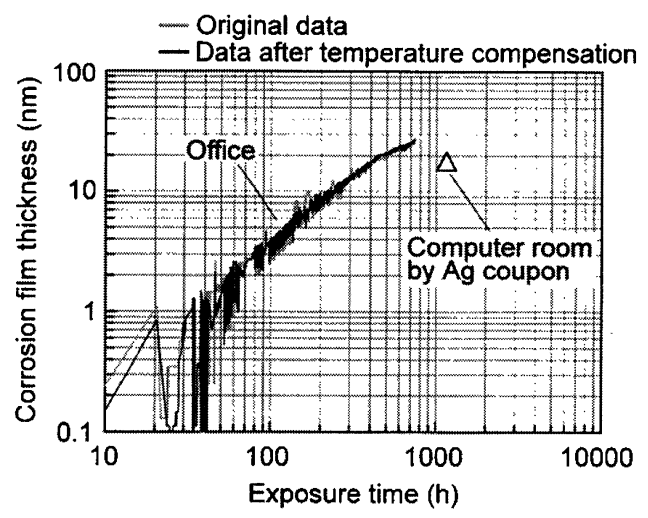

Fig. 14. Corrosion film thickness change of Ag film in electrical resistance type corrosion sensor exposed to an office with a computer installed.

厚さの変動ピークは, Fig. 15 で示した温度に対応して約 $24 \mathrm{~h}$ 周期であり, 温度変化がその原因と考えられる。そ こで, 温度係数と温度の測定值を用いて, $\mathrm{Ag}$ 薄膜電極 の電気抵抗の測定值を補正して求めた腐食厚さを Fig. 14 に併記した。これより，測定值の変動幅は，温度補正に より減少することを確認した. 腐食厚さに対する他の変 動要因としては，相対湿度の影響が考えられる。

\section{5. 考察}

\section{1 その場測定型腐食センサ}

混合ガス環境, 重工業プラントの電気室環境, 電子計 算機室を設置した事務所環境では, $\mathrm{Ag}$ 薄膜は $\mathrm{Ag}_{2} \mathrm{~S}$ のみ を形成する。この $\mathrm{Ag}_{2} \mathrm{~S}$ 腐食皮膜は保護性が低く，その 腐食厚さは直線則に従い増加した。これより, $\mathrm{Ag}$ 薄膜 は $\mathrm{Ag}$ 板試験片と同様の腐食挙動を示すことを確認した。 ただし， $\mathrm{Ag}$ 薄膜は, $\mathrm{Ag}$ 板に比べて表面積が大きく密度 が低いことに起因して，その腐食は約 $20 \%$ 促進した。し たがって，その場測定型腐食センサの $\mathrm{Ag}$ 薄膜と $\mathrm{Ag}$ 板試 験片の腐食厚さを比較する場合, その分の補正が必要と なる.

さらに，その場測定型腐食センサによる腐食厚さの目 視測定では，腐食皮膜が透明基板の界面まで到達してい なくても腐食皮膜の色が透過して観察される.混合ガス 環境に曝露した腐食センサの測定結果では, $24 〜 36 \mathrm{~nm}$

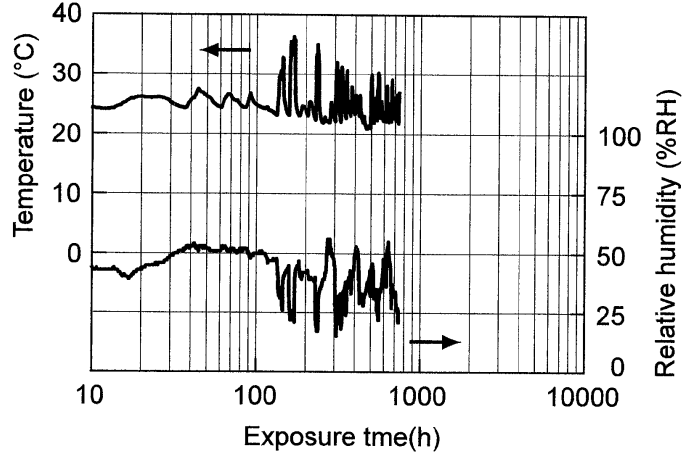

Fig. 15. Temperature and relative humidity change in an office with a computer installed.

の腐食厚さを過大評価する傾向が認められた。また，重 工業プラントの電気室に曝露した腐食センサの測定結果 では，XRFS 分析に基づく方法で測定した值を基準にし て厚さ $30 \mathrm{~nm}$ 以下の腐食皮膜を最大 $69 \mathrm{~nm}$ の腐食皮膜と して過大評価した。

その場測定型腐食センサは, 曝露期間で厚さ $30 \mathrm{~nm}$ 以 上の腐食皮膜が形成される環境, すなわち比較的腐食性 の強い環境を測定するのに適している。ささらに，XRFS 分析による方法を併用することにより, 腐食厚さを精度 良く測定できる。

\section{2 電気抵抗型腐食センサ}

電気抵抗型腐食センサは, $\mathrm{Ag}$ 薄膜からなる電極を採 用している。したがって, 電気抵抗型腐食センサの $\mathrm{Ag}$ 薄膜と $\mathrm{Ag}$ 板試験片の腐食厚さを比較する場合, その場 測定型腐食センサと同様に補正が必要となる. 電気抵抗 型腐食センサによる $\mathrm{Ag}$ 薄膜電極の腐食厚さの測定にあ たっては, 式 (3) で示した $R_{1}$ (曝露後の金属薄膜の抵抗 值) を $R_{0}$ (初期に打ける金属薄膜の抵抗值) と同じく $25^{\circ} \mathrm{C}$ での電気抵抗に温度補正する必要がある. なお，体 積抵抗率は, 曝露前後で変化しないため, 測定結果に影 響を及ぼさない。

電気抵抗型腐食センサで測定される腐食厚さは，原理 的に薄膜電極の形状によらず同じ值をとる.しかしなが ら試作した $\mathrm{Ag}$ 薄膜電極では, Fig. 13 に示したように約 60\%の腐食厚さのばらつきを生じた。これは，スパッ夕 薄膜の膜質及び寸法ばらつきによるものと考えられる. 腐食センサの実用化にあたっては, 成膜工程の管理及び 薄膜の検查が課題に挙げられる.

また，いずれの電極寸法の場合でも $30 \mathrm{~nm}$ 以上で腐食 厚さが直線則から外れて過大な值を示した. 混合ガス試 験環境の湿度は $75 \% \mathrm{RH}$ であり,この環境において清浄 な $\mathrm{Ag}$ 薄膜電極の表面には吸着水分子が島状に形成され ている ${ }^{14)}$ 。この島状に形成された吸着水分子下の $\mathrm{Ag}$ 薄 膜電極が局部的に腐食したことにより, 電気抵抗值が増 大したと考えられる. 局部腐食の影響は, 試作した電極 幅の寸法範囲では同程度である.さらに電極幅を広げれ ばこの影響は低減され, 電気抵抗型腐食センサで $30 \mathrm{~nm}$ 以上の腐食厚さの測定が可能になると考えられる.

今回試作した電気抵抗型腐食センサは, 曝露期間で厚 さ $30 \mathrm{~nm}$ 以下の腐食皮膜が形成される環境, すなわち比 較的腐食性の弱い環境を測定するのに適している．実環 
境では温度変動があるため, 温度補正した電気抵抗值を 用いて腐食厚さを算出する必要がある.

\section{3 腐食センサの適用}

今回試作したその場測定型腐食センサおよび電気抵抗 型腐食センサはいずれも電子装置の設置環境を評価でき ることを確認した。ただし，温湿度，腐食性ガス，塵埃 など電子部品に対する腐食要因は, 屋外の自然条件 (日 照, 通風, 降雨など）に加えて, 屋内の周囲条件（人の 出入り, 装置の起動停止など）に依存する。このため, 電子装置の設置環境の評価では，腐食センサによる腐食 量が測定時期と共に, 測定位置により変動することがあ $ろ^{6)}$. 測定時期のばらつきは，その場測定型センサでは 長期間曝露することで低減でき, また電気抵抗型センサ では単位時間あたりの腐食量からそれを評価できる。一 方, 測定位置のばらつきは，複数のセンサを用いて腐食 量の分布を評価する必要がある。この場合，腐食性の傾 向を把握することが目的であり，多数の箇所で腐食量を 同時に測定できるその場測定型センサが有効である。さ らに, 腐食性の弱い箇所に対しては, 定量性の良い電気 抵抗型腐食センサが有効である.

以上より，その場測定型腐食センサおよび電気抵抗型 腐食センサを併用することにより，電子装置の設置環境 の腐食性を評価するシステムを構築できる.

\section{6. 結}

\section{言}

電子装置の設置環境の腐食性を評価するシステムを構 築するために，腐食センサについて検討した。

（1）金属薄膜とその腐食皮膜との色調が異なることを 利用して金属薄膜の腐食厚さを測定するその場測定型腐 食センサ，腐食による電極形状の変化を電気抵抗の変化 として測定して金属薄膜の腐食厚さを算出する電気抵抗 型腐食センサを開発し, 銀薄膜からなる腐食センサを試 作した。

（2）試作した腐食センサの銀薄膜では，腐食厚さを補 正して銀板試験片と整合性を取ることにより，銀の腐食 厚さを精度良く測定できる。
（3）その場観察型腐食センサを重工業プラントの電気 室に曝露して, 腐食性ガスの発生しやすい工程の環境を 定量評価できた。 また，電気抵抗型腐食センサを一般の オフィスに曝露して, 一般のオフィス環境は, 専用の計 算機室に比べて腐食性が強いことを定量評価できた。試 作した腐食センサが電子装置の設置環境の腐食性を長期 に亘り測定できることを確認した.

（4）その場測定型腐食センサは曝露期間で厚さ $30 \mathrm{~nm}$ 以上の腐食皮膜が形成される比較的腐食性の強い環境, 電気抵抗型腐食センサはそれ以下の比較的腐食性の弱い 環境を測定するのに適している.

\section{参 考 文 献}

1）石川雄一, 尾崎敏範, 日本材料学会腐食防食部門委員会第 200 回例会資料, p.28 (1997)

2) JEIDA-63-2000, "Standard for Operating Conditions of Industrial Computer Control System (Jpn.)", Japan Electronic Industry Development Association (2000).

3) ISA-S71.04-1985, "Environmental Condition for Process Measurement and Control Systems, Airborne Contaminants", the Instrument Society of America (1986).

4) CEI/IEC 654-4-1987, "Operating conditions for industrialprocess measurement and control equipment Part 4, Corrosive and erosive influences", International Electrotechnical Commission (1987).

5) T. Iikawa, Y Udo and E. Nakajima, Corrosion Science, 35, 735 (1993).

6) M. Watanabe, N. Aoki and K. Ikeda, Electrochemical Society Proceeding, 99-29, p.75 (1999).

7) Ed. by JSCE, "Corrosion of Electronic and Magnetic Materials (Jpn.)", Japanese Standard Association, p.25 (1993).

8) N. Sawayama, Plant Engineer, 2, 64 (1995).

9) M. Kishimoto, Proc. 9th International Conference on Electric Contact Phenomena, p.377 (1978).

10) S. J. Krumbein, B. Newell and V. Pascucci, Journal of Testing and Evaluation, 17, 357 (1989).

11) Ed. by NAOJ, "Chronological Scientific Tables (Jpn.)", Maruzen, (2003).

12) S. Shiga, N. Shibata, H. Suda and A. Matsuda, Furukawa Review, 76, 93 (1985).

13）平本抽，秋本昌子，田中美和子，野見山敦子，日本材料 学会腐食防食部門委員会第 46 回研究集会資料, p.1 (1997).

14) S. Okido and Y. Ishikawa, Boshoku Gijutsu (presently Zairyo-to-Kankyo), 47, 173 (1998).

(Manuscript received December 28, 2004 in final form June 23,2005 )

\section{要旨}

電子装置を設置した環境の腐食性を評価するために，その場測定型腐食センサ，㧍よび電気抵抗型腐食 センサを開発した。その場観察型腐食センサは，薄膜金属とその腐食生成物との色調が異なることを利用 して，特別な分析機器を必要とせずに薄膜金属の腐食量を半定量化できる．また，電気抵抗型腐食センサ は，対象となる金属薄膜が腐食するにつれて電気抵抗が変化することを利用して，薄膜金属の腐食量を精 度よく連続測定できる. 本報告では，電子材料として多用されている銀に注目して，銀薄膜からなる腐食 センサを試作した。まず，腐食センサの銀薄膜と従来の銀板試験片の腐食挙動を比較検討した。混合ガス 環境に打いて銀薄膜は，銀板試験片と同じメカニズムで腐食したことから，腐食センサは銀板試験片に代 わって腐食環境に扔ける銀の腐食厚さを測定できることがわかった。さらに，腐食センサにより重工業プ ラントの電気室環境, および一般オフィス環境の腐食性を評価した。 その結果, その場観察型腐食センサ は強腐食性環境を，電気抵抗型腐食センサは弱腐食性環境を評価するのに適していることがわかった．以 上より，腐食センサは電子装置の設置環境の腐食性を評価するのに有効なセンサといえる.

キーワード＼cjkstart腐食センサ，その場測定，電気抵抗測定，大気腐食，腐食性ガス，電子装置 